\title{
Shaping Public Opinion for Confrontation: Catalan Independence Claims as Represented in Spanish, Catalan, Valencian, and Basque Editorials*
}

American Behavioral Scientist 2017, Vol. 6I(9) 1040-1055

(c) 2017 SAGE Publications Reprints and permissions: sagepub.com/journalsPermissions.nav DOI: $10.1177 / 0002764217708587$ journals.sagepub.com/home/abs

@SAGE

\author{
Enric Xicoy', Cristina Perales-García², \\ and Rafael Xambó ${ }^{3}$
}

\begin{abstract}
Editorials represent a newspaper's principal means of ideological positioning and serve to identify the attitude of each newspaper and its readership to some of the main actors in any given conflict, especially those that are political in nature. Catalonia's independence movement has experienced a surge in recent years. The turning point came in July 2010, after Spain's constitutional court ruled against some aspects of Catalonia's Statute of Autonomy (the legislation regulating the relationship between the Catalan autonomous community and the Spanish state). The ruling annulled some of the articles of the statute. The demonstration in support of Catalan independence that took place on September II, 2012, was considered the most important among several mass rallies held for this purpose over successive years on Catalonia's National Day. This article presents the results of a qualitative and quantitative analysis of editorial articles published around these two key dates, with the goal of studying each newspaper's treatment of political actors and their degree of identification with these actors. Their use of arguments aimed at persuading readers and legitimizing a given position during the specified time periods in 2010 and 2012 will also be studied. The study focuses on the editorial articles published by several newspapers in four distinct regional contexts: Catalonia, Valencia, the Basque Country, as well as the
\end{abstract}

\footnotetext{
'Blanquerna Universitat Ramon Llull, Barcelona, Spain

2Universitat Pompeu Fabra, Barcelona, Spain

${ }^{3}$ Universitat de Valencia, Valencia, Spain

*Translated from Spanish
}

\section{Corresponding Author:}

Enric Xicoy, Blanquerna Universitat Ramon Llull, Plaça Joan Coromines, s/n Barcelona 0800I, Spain.

Email: enricxc@blanquerna.edu 
whole of Spain. The analyzed articles were published a few days before and after July 10, 20I0, and September II, 2012.

\section{Keywords}

newspaper editorial, politics of Spain, Catalan independence movement, political reporting, political legitimacy

\section{Introduction and Context}

To trace the historical and political context of this content analysis back to the year 1714 may seem somewhat bold. It might appear less so, however, if we consider that 2 years ago Catalonia commemorated the 300th anniversary of Onze de Setembre (September 11), the date, in 1714, when the Bourbon, Spanish, and French armies put an end to the siege of Barcelona, thus abolishing the Catalan constitution and its freedoms. The date also marks Catalonia's National Day, known as the Diada. The September 11, 2014, anniversary served to bring to the fore certain historical facts that have forever shaped the fate of the Catalan nation.

Aside from this more historical perspective, the task of analyzing a newspaper's political coverage of the 2012 Diada and of the mass demonstrations of July 10, 2010, requires taking into consideration more recent events. Arguing that Catalonia's 1978 Statute of Autonomy was inadequate, obsolete, and ill-suited to the context of the 21st century, Catalan political parties set out to rewrite it in 2005, with the goal of gaining greater sovereignty for Catalonia. The Spanish parliament overwhelmingly supported the final, albeit watered-down, version of the text that was put to a vote in 2006, with the backing of the then governing Socialist Party (PSOE) led by José Luis Rodríguez Zapatero.

The People's Party, then in the opposition, challenged the statute's legality in Spain's constitutional court. Their subsequent ruling forced the amendment of the more controversial articles, generating broad social and political repudiation. The ruling was issued on July 9, 2010, the day before a planned demonstration called to demand the court's support for the statute. The unfavorable ruling increased participation in the demonstration and gave it a clearly separatist tone. From that point on, separatist sentiment became more and more widespread; at present, according to most surveys, it represents the point of view of the majority. This fact became apparent on another demonstration, the rally held to mark the Diada on September 11, 2012. On that day, more than a million marchers stood behind a banner that read "Catalonia, a new country in Europe," it was one of the largest demonstrations in the history of Catalonia. Other mass rallies to mark the Diada would follow in 2013, 2014, 2015, and 2016. These rallies, together with the nonbinding referendum of November 9, 2014, have had a significant affect internationally, putting the so-called "Catalan independence process" on Europe's political agenda. The nonbinding referendum asked voters the double question, "Do you want Catalonia to be a state?" and "If so, do you want Catalonia to be an independent state?" Therefore, politically speaking, after July 10, 2010, and the 2012 Diada, nothing has been the same in Catalonia. That is why we deem it both relevant and necessary to analyze how the main Spanish and Catalan newspapers covered the events that took place around those dates. 
The so-called Catalan Independence process is one of the clearest examples of a popular movement in Europe today and practically has no precedents and few similarities with other movements. Perhaps the desire shown by a large number of Scots to no longer form part of the United Kingdom comes closest. The difference is that the Scottish separatist movement has been led by the Scottish Nationalist Party, while in Catalonia it has been civil society organizations such as the National Assembly or the Catalan Cultural Omnium that have provided the main inspiration. There are some similarities, however, with popular movements such as the Spanish 15M grouping or certain social revolutions in Latin America or the Arab Spring that have managed to change the hegemony of the political status quo in the countries in which they have emerged.

\section{Theoretical Framework}

The preeminent role of the media in the articulation of the public sphere, especially with regard to the flow of information and the creation of public opinion, is essential to understanding recent political developments in Catalonia, the so-called Catalan transition or "Catalan process."

We start from the premise that newspapers remain powerful institutions that play an important role in shaping public opinion. As Héctor Borrat (1989) noted in the 1980s, the media are political actors, and as such they intervene in the conflicts they cover, amplifying them, modifying them, and shaping them. The social construction of reality, as defined by Berger and Luckmann (1968), is a process whereby certain practices and roles become institutionalized. As coconstructors of social (and political) reality, the media also play a role as coconstructors of identity.

Editorials should be viewed as the privileged voice of a newspaper (Perales, 2012), as they represent a given media outlet's ideological position vis-à-vis the issues it considers relevant, employing discursive strategies that are based on persuasion and often result in simplistic and reductionist interpretations of the issues.

[... ] editorials usually employ the language of public interest, a language that caters to powerful decision-making elites and opinion leaders who are able to process the arguments being put forward and transmit them without distorting their full meaning. Therein lies their selective relevance. (Gomis, 1989, p. 172)

It is through these articles that media outlets reveal their ideological map, in language that is undeniably political. As actors, they report on and opine on political issues, with the goal of positioning themselves politically and influencing their audience.

\section{Methodology}

\section{Objective and Hypothesis}

The main objective of this work is to analyze the op-ed discourse of daily newspapers in four ideologically distinct contexts: (a) the Catalan context, (b) the Spanish context, (c) the Basque context, and (d) the Valencian context. The overall aim of this article is expressed through the following more specific objectives: 
- To study the editorial positioning of the chosen newspapers.

- To analyze and discuss the reasoning - and arguments - employed in op-ed pieces for the dissemination of a particular representation of the issues at hand.

The general hypothesis that we intend to test is twofold:

- Daily newspapers have taken an active role in the interterritorial conflict between Catalonia and the rest of Spain, positioning themselves in line with the model which they feel should be applied to fit the two together.

- The discourse put forward by the newspapers is consistent with specific political strategies and narratives.

\section{Sample and Methodology}

The time bracket in which the op-ed pieces in our sample were published covers 1 week before and after the demonstration of July 10, 2010 (from July 3 to July 17, 2010 , both inclusive), as this was the period that concentrated the most media attention. With regard to the events of 2012, the analyzed editorials were published between September 3 and 30, 2012. This period includes the social mobilization that took place prior to the 2012 Diada; the demonstration on September 11; as well as subsequent events such as the meeting at the Moncloa Palace (the seat of the Spanish government) between president Mariano Rajoy and Catalan president Artur Mas (October 20, 2012); and finally, the announcement of early elections in Catalonia (October 27, 2012). This sample is significant enough, as it shows the media's evolving position on the mass demonstrations and their subsequent consequences.

The sample comprises editorial articles that appeared in the following newspapers: La Vanguardia, El Periódico de Catalunya, El País; El Mundo, El Correo, Deia, Levante-El Mercantil Valenciano (EMV), and Las Provincias. In each case, our selection criteria has favored the two newspapers with the highest circulation in each of the regions in Spain where nationalist claims have given rise to conflict:

- The Catalan context: The chosen dailies focus their coverage on Catalonia and provide general information as well. La Vanguardia and El Periódico de Catalunya have separate editions in Spanish and Catalan.

- The Spanish context: El Mundo and El Pais are national, generalist newspapers, published in Madrid in Spanish.

- The Basque context: The chosen dailies focus their coverage on the Basque Country, where they are based. El Correo is written in Spanish, while Deia is published in a bilingual edition (Basque and Spanish). Both offer general information.

- The Valencian context: Levante-EMV and Las Provincias are the main, generalist, newspapers in the Valencia region. They are published in Spanish. 
The Basque and Valencian dailies offer a window into the institutional opinion of the regional governments of the Valencian and Basque autonomous communities, two regions that have traditionally displayed nationalist sentiment, although from different perspectives.

The following table shows the total number of articles that make up the body of the work:

\begin{tabular}{lcc}
\hline & \multicolumn{2}{c}{ Op-ed pieces } \\
\cline { 2 - 3 } Newspapers & $07 / 10 / 2010,15$ days & $09 / 1$ I/2012, 28 days \\
\hline El Periódico de Catalunya & 6 & 9 \\
La Vanguardia & 6 & 10 \\
El Mundo & 9 & 14 \\
El País & 4 & 8 \\
Deia & 2 & 4 \\
El Correo & 3 & 7 \\
Levante-EMV & 1 & 0 \\
Las Provincias & 8 & 8 \\
Total & 39 & 60 \\
\hline
\end{tabular}

We believe that our media sample is sufficiently representative, and that the 99 opinion articles that constitute the body of our work make up a sample of articles sufficiently robust and representative to enable us to recreate the ideological matrix of each newspaper. The study will, on the one hand, analyze each newspaper's editorial position, while also comparing the papers' positions, both within each media context (the Catalan context, the Spanish context, the Basque context, and the Valencian context) and between contexts.

\section{Results}

Below are the main results of our analysis. They will be presented in blocks in accordance with the context of (a) Catalan newspapers, (b) Spanish newspapers, (c) Basque newspapers, and (d) Valencian newspapers.

\section{Catalan Newspapers, July 10, 2010}

Six editorials appeared in El Periódico de Catalunya. The main conclusions gleaned from the analysis are as follows: (a) It is up to Montilla to seek unity and (b) if he does not achieve it, then it is up to the Convergència i Unió (CiU). For example, the first editorial, of July 7, states that Montilla wants "us to travel together," but the CiU went for the slogan of Omnium Cultural in order to "wear down the tripartite and the President rather than opting for loyalty." Something similar was stated on July 10, referring to a "final pirouette." Referring to the Constitutional Court's sentence, it is 
stated that negotiations with the Spanish government are needed in order to achieve what the "Constitutional Court has stolen from us"- the line defended by the Socialists Party of Catalonia (PSC). On the 15th, the editorial insists there is a lack of agreement on a joint resolution on the judgement and blames the tripartite on the one hand and $\mathrm{CiU}$ on the other. On July 17, the editorial is dedicated to the agreement in extremis that Montilla achieved. This is described as "Not much," but "unity offers little more."

La Vanguardia published six editorials during the 15 days analyzed: on July 4, 9, $11,15,16$, and 17 . The editorials on July 15 and 16 deal with the Debate on the State of the Nation. The first three, closely linked to the ruling and the demonstration, coincide in criticizing the judgement of the Constitutional Court, though in different degrees. They affirm that "there are grounds for a demonstration" but relativize this by stating: "The ruling is not catastrophic." They justify the demonstration; though make it clear that the "true depth of Catalan opinion" should be gauged "as soon as possible through the ballot box." The newspaper argues, implicitly, that the tripartite is not working. But it concludes that after the process "nothing will ever be the same."

Days 15 and 16 focused on the State of the Nation Debate. The articles state that the best speech in Congress was given by Josep Antoni Duran i Lleida, of CiU, who certified "the end of Zapatero's credit" as his promises to amend the statute were merely a "futile attempt to keep on good terms with an aggrieved Catalonia." The last editorial analyzed, on July 17, reveals a position in favor of Artur Mas. It states, we need to "value his generosity" in giving "a blank cheque to the President [Montilla] allowing him to position himself in comfort." The newspaper criticizes Montilla for opening the debate "without a specific proposal" and for not being "ambitious enough."

\section{Catalan Newspapers, September II, 2012}

El Periódico published one less editorial (9) than La Vanguardia. Until the day of the Diada, it did not publish any. However, after that it displayed three in a row on September 11, 12, and 13 .

In those early days, it warned that "perhaps there is no overwhelming majority in favour of independence now, but it will not be long in coming if the central government continues to ignore how Catalans are feeling." It also demands a meeting and an agreement between Mas and Rajoy; a highly unlikely outcome according to $E l$ Periodico, because Mas is encouraging, "for electoral interests, vain expectations that will generate more frustration."

It is not till September 17 that we find an editorial stance centerd exclusively on the PSC's position on the process. El Periódico has traditionally been associated, ideologically, with socialist positions, though it also speculates if the socialist way is the correct strategy: "Is it still possible to attempt to introduce a federal plan? Much has been said about it, but little has ever been put into practice."

The fifth editorial, on the 19th, refers to a speech by King Juan Carlos I. Interestingly, the only Catalan newspaper that did not bring the speech up in its editorial was $L a$ Vanguardia. It was described as a "Forceful royal intervention" in the headline. Despite that, it was not condemned or criticized, quite the opposite. First, it explains and 
contextualizes the meeting, the following day, between Rajoy and Mas and sees that as the model to follow because "Rajoy and Mas will have the opportunity to demonstrate through flexibility and pragmatism on both sides, that the floodgates can still be closed. It is not sure that this is the case, but otherwise, a deluge will be inevitable."

Editorials dedicated new articles to the meeting of Rajoy and Mas. Even though the meeting did not go well, it stated: "El Periódico continues to demand political lucidity and intelligence for the benefit of the whole of Catalan society." Finally, there is the General Policy Debate in the Catalan Parliament that saw off Mas's proposal for new elections and criticized it thus: "It's time to pay the bills, take stock and explain future plans, including in the field of cuts." This sentence summarizes the positions of $E l$ Periódico at this time. The other was that before going down the road to independence, it was necessary to consolidate a pact with the Spanish government without denigrating the demonstration on September 11.

As aforementioned, La Vanguardia published an editorial on little more than a third of the days analyzed, that is, 10 out of 28 days. Although the demonstration had been an issue discussed for some days previously, La Vanguardia took time making reference to it, arguing that it would represent the sum of popular unrest and nationalist demands. It did not believe that the people who would attend the demonstration were all in favor of independence, "nevertheless, the march, called for Tuesday, will unite explicit separatists with many citizens who, without having a defined position, wish to express their unease with what they consider to be constant attacks on Catalonia." This was a thesis the paper would maintain the following day stating it was "a serious warning that the central government needs to take into account."

In the article "The Eleventh of September at the Moncloa," news was given of Mas's next visit, just 4 days later, to La Moncloa. The "current model governing the relationship between Catalonia and Spain" is considered moribund. It states,

Catalonia will dialogue with and demonstrate to Europe that the language and tone of the demonstration on September 11, with its exemplary civic and peaceful behaviour, has not been exhausted; rather a will to dialogue will pervade the whole process that has now opened up.

Curiously, 3 days later, on the 19th, the King published his controversial letter online, which as aforementioned, the paper overlooked in its editorial.

At the end of the days studied, it concludes:

The President of the Generalitat (Catalan Government) has been able to intelligently interpret the political will of the protesters and has taken the initiative of calling early elections which, whether we like it or not, will take on a plebiscitary character and question the country's desire to form its own state.

It was a text, therefore, that essentially served as a conclusion on the main idea supported during this period that Artur Mas is the leader to follow in this time of uncertainty. 


\section{Spanish Newspapers, July 10, 2010}

El Mundo dedicated nine editorials to the topic. It focused particularly on the perceived "mockery" that the ruling of the Constitutional Court had sparked, and, in particular, on criticizing the political figure of Montilla. First, direct criticism of the Constitutional Court revolved around arguments relating to the lack of forcefulness of the ruling since it "only" declared 14 articles unconstitutional. "It would have been more coherent to have declared the whole statute unconstitutional."

It played down the role of Omnium Cultural in convening and organizing the march. For this newspaper, the event served as a "springboard" to independence through what they called "radical nationalism." This Madrid-based daily stated that Montilla should not have led the rally. It also used the occasion to criticize Zapatero for having previously declared that he would accept the Statute if it were approved by the Catalan Parliament. It also decried Montilla as: "A puppet in the hands of the separatists"; accusing him of being "irresponsible," a representative of the State who is refusing to comply with the Law"; "Montilla has lost the plot"; or "he is deranged." The article ends by concluding that he should leave the Catalan Government.

El Pais dedicates four editorials to the subject, on July 4, 10,11, and 15. The newspaper initially lined up in favor of the court's ruling and the constitution. The daily had no doubt: "what we must all do is stick by it." However, its position evolved after that first editorial. The second was titled "Mediocre Ruling." Although the newspaper was in favor of accepting the sentence, it suggests that the Catalans had been manipulated by nationalist political parties in favor of independence:

Interpreting the demonstration yesterday as a sign of mass support by Catalonia's citizens for the Catalan Statute does not fit the fact that there was a low turnout in the referendum approving the statute, nor was such support reflected in the banners unfurled and the slogans shouted on the demonstration.

It also played down the organizational role of cultural bodies in Catalonia. We can conclude that the newspaper is fully behind the constitution and is determined to delegitimize any questioning of the territorial organization of Spain.

\section{Spanish Newspapers, September II, 2012}

El Mundo published 13 editorials. They were articles from September 11 itself, the day the separatist demonstration had been called. In nine cases, the conflict dominates the opening sentences of the articles, while in the other editorials it is the second, third, or fourth issue of the day.

All of them argue against the independence-minded proposal, which is seen as an action orchestrated by Artur Mas and considered a "vibrant assertion in favour of independence." Mas defending the sovereignty of Catalonia is seen as "crossing a redline." They also reproach Rajoy for not having responded more firmly on the issue. They claim that "the protesters ignored Mas' position and converted the demonstration into 
a demand for independence that clearly expressed a desire to break all links with the rest of Spain." They also criticized the Socialist MPs who attended the event.

The writer of the editorial compares Mas with Dr. Frankenstein: "the monster he created in his laboratory, as an experiment, took on a life of its own, leading to untold damage that its creator had not calculated on."

The newspaper warned that Catalonia would be expelled from the Euro Zone and the European Union in the event that it declared itself independent. It delegitimized Mas, comparing him unfavorably with the Basque President, Urkullu, described as a model president and politician. It also condemned Rajoy as a weak leader, who should "make a move" and "anticipate events." Although they also state: "It must be recognized that Mariano Rajoy has acted appropriately to date."

However, using weighty arguments, the paper asserts that,

various sanctioned voices in civil society, along with experienced politicians of all stripes have stressed that the autonomous model created by the Spanish Constitution of 1978, or rather the unchecked expansionism of its communities, has become a hindrance for Spain.

It goes on to point out that the PSOE is "out of touch with reality" by continuing to argue for a federal state.

During the period under review, the newspaper, El Pais published eight editorial articles; all of them on the same day as the Diada or on the subsequent days. Roughly the newspaper is in favor of federalist proposals, but is also markedly Spanish in character. There is no consideration of the possible independence of Catalonia. That said, the leader writer notes that the tense relationship between Rajoy and Mas, along with a lack of flexibility from the Central Government, are leading to a radicalization of Catalan nationalist positions.

It is a small evolution from the argument made in the first editorial and in the other articles. The first article, titled: "Historic Diada," published on September 12, argues in favor of the demonstration, justifying it as a social movement which acts as an umbrella for disparate political tendencies, from independence seekers to those demanding a new financial model. However, they accuse the governing party of being opportunists for whom "[the situation] has diverted attention from social services cuts and from CiU's responsibility in worsening the Catalan debt." The newspaper even recognizes that "the demonstration is a strong public message for the rest of Spain" which pivots on Mas, who sees himself as "the head of a national transition movement in Catalonia." The newspaper shows no sympathy toward Mas, but Rajoy does not come off well either. The leader does not support the intervention of the King. It considers that calling Catalan aspirations: "pursuing chimeras" is a mistake and argues that the King must stay on the sidelines and abide by the decisions and strategies of his Governments, since it is they who have to solve the issue.

The paper notes that the PSOE has been largely absent from the debate, or else centers on the Rajoy-Mas conflict. "It also singles out ex-Spanish Prime Minister, José María Aznar, as one of the culprits of the radicalization in Spain." 
The "viable" and "sensible" alternative that the newspaper proposes is of a federalist nature. It is argued that this would allow the maintenance of the current state of the autonomies, seen as a guarantor of welfare and prosperity. Despite this, the newspaper considers that "any proposal has legitimacy." It is on this point that we see an evolution in the paper's reasoning, since in the following days the argument it puts forward rejects any secessionist proposal that is in conflict with the established constitution.

\section{Basque Newspapers, July 10, 2010}

Only on 2 days out of 15 did the editorial in Deia cover the subject: July 7 and 11. Its headlines were as follows: "Beyond the Constitution" and "Catalonia answers as a nation." The newspaper argues for an urgent reform of the Constitutional Court in order to avoid "the political abuse," which according to Deia exists when it comes to interpreting the clauses of the constitution. It condemns the current lack of independence between the political powers and the judiciary. The editorial of July 7 explicitly states that the Constitutional Court demonstrates a lack of democracy when it vetoes the aspirations of Spain's other nations. It clearly positions itself in favor of self-determination and considers the court's ruling an error. The second editorial, commenting on the Diada is direct, when it comes to the ideological convictions of the newspaper: Catalonia is a nation and that has been ratified by its citizens in an "impressive and historic demonstration." The newspaper reminds its readers that whatever affects Catalan sovereignty also affects Basque sovereignty.

The newspaper El Correo published three editorials: on July 10, 12, and 17. All are from the day of the demonstration and none are the leading editorial. The three texts are well argued and contain elements placing the events in context. With regard to the demonstration, the paper affirms that "it would be inappropriate" for it to be able to "annul the ruling and the authority of the Constitutional Court." In other words, the demonstration ought not to delegitimize the court's ruling. Deia asks the Catalan Executive to explain how they would administer the "maximum self-government that the court's ruling offers." The editorials that followed dealt with the relationship between Montilla and Zapatero. They all attempt to point out the conflicts that exist between the positions of the two presidents, stressing that the President of the Generalitat has a difficult task in hand, because he must find a balance between identity-based demands and Zapatero's promises. It makes it clear that Catalonia should have little cause for complaint, despite the ruling.

\section{Basque Newspapers, September II, 2012}

The newspaper Deia wrote four editorials on Catalonia's Diada; two prior to, and another two after, the demonstration of September 11. The newspaper warned that as a result of the policy of "recentralization" that the Rajoy Government has been putting into practice, "the autonomous communities will cease to be autonomous by virtue of central control of their finances by the Government in Madrid . . . and its political interests and affinities." The paper reminds readers of the example of Quebec, stating 
that the "triumph of the Quebecois Party" in recent elections is not an isolated event, but the voice of a "nation" with a historical demand for the recognition of its right to equality and to not being subordinated to another nation in the international context.

The demonstration of September 11, 2012, was "the strongest and most numerous expression of support by ordinary citizens for any political initiative that there has ever been in Catalonia. It is nothing less than a reflection of the wide ranging disaffection of Catalan society towards Spain." For Deia, the public response on the Diada was an expression of disaffection toward Spain due to a "lack of comprehension, as well as the arrogance of those currently directing Spain and to a failure to respond to Catalan demands for a reform of the relationship between the two nations." It is manifestly favorable to the demonstration; not for nothing the title of the editorial was "The Seed of the Catalan State." It adds that Rajoy has rejected "the desire of a civil and democratic majority in one of Spain's historical nations."

The Basque newspaper El Correo published seven editorials during the period covered by this study. All of them after the demonstration on the Diada. For El Correo, the demonstration had tensed further the relationship between Spain and Catalonia and had "fostered an attitude favorable to independence," an issue it does not look on favorably, branding it a "devilish dilemma" and considering it all part of Mas's political strategy. The newspaper calls for a continued commitment to the current system of regional autonomies because it is seen as a sign of "moderation and rationality in expressing common interests and in the fulfilment of legitimate aspirations." The written statements made by the highest political institution of the state, the crown, about the demonstration and defending self-determination are seen as "appropriate" and necessary since they represent "a warning against division." The paper notes that the King is the guarantor of democratic values which "will prove capable of overcoming current obstacles."

In short, the issue is presented as "the Catalan problem" and seen as "grave and frightening." This is blamed on an "ambivalent strategy" by CiU who appeared ambiguous when clarifying whether they advocated independence or another model by which Catalonia would fit into the Spanish jigsaw.

\section{Valencian Newspapers, July 10, 2010}

During the 15 days under analysis, the newspaper Levante-EMV, which belongs to the Prensa Ibérica group, only published one editorial on the issue, on July 13. There was nothing the day after the ruling of the Constitutional Court nor the day after the demonstration. Under the headline "Articulating Spain," the editorial concludes with the idea that "the Spanish jigsaw" is still suffering a "spirit of deception" and is "hostage to the disaster" born out of having to face emerging realities "linked to modernity." It concludes that the decision of the Constitutional Court "is a severe reading of two opposing ideologies." It claims the People's Party is attempting to close up autonomous Spain by fallaciously absorbing the Constitution, which is an "immutable" element. It also accuses the PSOE of "frivolously unleashing the idea of a plural Spain." 
Las Provincias dedicated eight editorials to the issue within the 15 days analyzed. In six cases, it was the main editorial leader. The majority presented the position of the newspaper as being in favor of the defence of constitutional order, with little or no context. In addition, it presents the process as a Manichean scheme in which Catalonia is portrayed as sowing conflict to abandon the constitutional path. A brief analysis allows us to summarize the editorial of July 4, which says that the Generalitat should moderate its views and continue down the "constitutional path." It warns of the "separatist bias" of the demonstration and of the "danger of the spread of powers challenging the Constitutional Court" in other autonomous communities." On the 5th, it continues to insist that the sentence must abided by. On the 10th, the day of the demonstration, the editorial leader considers "unacceptable" the "conflict of legitimacies" between the Statute and the Constitutional Court's ruling and calls on the Generalitat not to exceed the limits "of its existing Statute and the Constitution." On Sunday, the 11th, the main editorial discusses the World Cup Final, which it uses to celebrate the "normalization of patriotism," "distanced from rhetorical nationalist urges." The second editorial titled "Catalan Irritation" stressed "the confused tone of the protest," the "letting off of angry steam," the "slippery slope process," and public "weariness." It concluded by insisting all energies should be focused "on the greater objective of getting out of the crisis and restoring lost prosperity." The effects of leverage are evident between the first and second editorials.

Editorials on the 12th and 15th insist there was a "demand for independence" on the demonstration and they note the pressure on Montilla, who the editorials advise to distance himself from the CiU, "moderate his demands" and "stick to the constitutional framework." On the 16th, in response to Zapatero's declaration that he recognized Catalonia "as a nation in political terms," the editorial highlights the "incomprehension and open rejection of that statement by ample sectors of Spanish society." It also stresses the effects that revising current laws on autonomic status could have in other regions. The last editorial on the 17th, titled "Disunity in Catalonia," attacks the PSC for having participated in the demonstration, using the caption "unacceptable."

\section{Valencian Newspapers, September II, 2012}

The newspaper Las Provincias, belonging, like El Correo, to the Vocento Group, devotes eight editorials to the topic during the 28 days analyzed. The first editorial came out on the day after the demonstration on the Diada. The headline, "Drift towards independence," is expressive of the position adopted by the newspaper, which views demands for national rights, in a negative light, as "threatening to break the seams of Spain and its autonomies" provoking a "devilish dilemma" that "could threaten the current autonomous nature of Spain and its internal cohesion which could lead to putting real sovereign power in the hands of the Generalitat," an idea that is considered a "profoundly selfish vision that is the antithesis of solidarity." The editorial is almost identical to that of El Correo. 
The following editorial on September 16, is titled "Protest Against the Cuts." Although ostensibly a pronouncement against a possible general strike, the article uses the opportunity to refer to "the unsettling demonstrations on Catalonia's Diada." The following day, the 17th, the newspaper was already directly blaming Catalonia for a secessionist crisis, stating "it would appear pertinent that the two largest parties arbitrate a solution to the secessionist crisis in Catalonia." The editorial praises the position of Rubalcaba, who, referring to Mas, said, "If he wants to break with Spain, he is going to have us against him."

The following two editorials, on September 19 and 23, were centered on the King. The first titled "Indispensable Minimums" backed up the usual rhetoric of the monarch: "recognizing diversity," "finding within a legal and political framework a broad based means of expression," "solidarity agreements in an essentially plural country." The second focuses on praising what it considers "greater transparency and the feverish public activity that will help the country out of the crisis."

The day after this editorial, the 24th, the leader has the headline: "Rajoy descends into the political arena" in order to fight in the "political battle" and take charge of the "grave and dramatic Catalan problem," so as not to increase "our creditors' lack of confidence." The editorial ends by demanding tact, dedication, and dialogue "after the havoc caused by independence seekers." The resolution proposed by the CiU before the Catalan Parliament is the subject of an editorial on the 25th, where it is described as an "ambivalent strategy" designed to simulate "an attempt at a referendum that will lead to the dissolving of parliament and the holding of new elections" or to the direct calling of them.

The last editorial analyzed, on the 26th, attacks the $\mathrm{CiU}$ for what it understands as a "political fiasco," the calling of new elections designed to increase the party's electoral support. It concludes by considering the electoral process "an adventure down a fearful path" at the same time as demanding explanations about the procedures necessary to deal with the problems.

There are great lexical similarities, even entire identical paragraphs, between the editorials in El Correo and those in Las Provincias, which leads us to infer the existence of a clear editorial line that Vocento are insisting on in the newspapers in their group, a line that is adjusted in each territory to fit certain sociopolitical characteristics.

The newspaper Levante-EMV, belonging to the Prensa Ibérica Group, did not mention Catalonia in a single editorial in September. Levante-EMV shies away from positioning itself; it avoids facing a conflict that its rival paper clearly feeds. It simply limits itself to quoting information provided by the EFE news agency.

\section{Conclusions}

1. An initial, merely quantitative, approach to the data suggests that generalist newspapers distributed in Catalonia and in the whole of Spain gave the most op-ed coverage to the events, with El Mundo devoting the most attention to them. This demonstrates that the Catalan conflict has been the main political issue in Spain in recent years. It is another question what the media have to say 
about it. It should be noted that, had we included Catalan proindependence newspapers in our sample, these would have had a disproportionate representation in terms of number of editorials. As for the Basque and Valencian dailies, it seems only natural, considering they cover the issues in their own regions that they should devote less op-ed space to the Catalan question.

2. The main finding of our content analysis is that the Catalan newspapers justify the 2010 demonstration by criticizing the constitutional court's ruling and demand a negotiated solution. As for the events of 2012, La Vanguardia calls for early elections; at no time does it espouse the separatist cause, although it does regard the regional election as a plebiscite of sorts on the question of independence. El Periódico is the paper that least insists on the Catalan people's so-called "right to decide." It advocates for an agreement between the Spanish and Catalan governments to avoid reaching a final breaking point; it also insists that the breakaway process should not be used to divert attention from the cutbacks implemented by the $\mathrm{CiU}$ regional government.

3. The Spanish and Valencian dailies, as well as the Basque newspaper El Correo, support the court's decision and defend the unity of Spain, arguing that Catalonia has no inherent right to self-rule. The main argument is a vehement defense of the Spanish constitution, regarded as inviolable and untouchable by El Mundo and the newspapers belonging to the Vocento group, while according to the newspaper El Pais, the constitution can only be modified by the Spanish people as a whole, the only sovereign body entitled to do so.

4. Deia does question the legitimacy of the constitutional court's ruling and is the only non-Catalan newspaper in our sample that recognizes Catalonia's right to decide, criticizes the central government's recalcitrance in failing to accept the fiscal pact and presses it to consider Catalonia's proposal.

5. There is a clear polarization between the Catalan newspapers (plus Deia) and the remaining dailies whose editorials we have analyzed. Nevertheless, as we have pointed out, this polarization would be far more pronounced if we had included in our sample the separatist Catalan newspapers whose editorial stance differs starkly from the more conservative, prostatus quo views of $L a$ Vanguardia and El Periódico.

6. There is noticeably little attention given to political actors other than Mas and Rajoy, especially in the 2012 analysis.

7. Generally speaking, the most nationalist papers, both on the Catalan and Spanish sides, display the classic elements of propaganda-like polarization: We are the good guys, they are the bad.

8. In conclusion, the undeniable novelty represented by the 2012 Diada, which began to take shape on July 10, 2010, has been the emergence in Catalonia of widespread separatist sentiment, along with new discursive, economic, and legal elements linked to the financial crisis, while the majority discourse outside Catalonia continues to be the denial of Catalonia's right to decide. 


\section{Declaration of Conflicting Interests}

The author(s) declared no potential conflicts of interest with respect to the research, authorship, and/or publication of this article.

\section{Funding}

The author(s) received no financial support for the research, authorship, and/or publication of this article.

\section{References}

Bourdieu, P. (1987). Espacio social y poder simbólico. In P. Bourdieu (Ed.), Cosas dichas (pp. 127-142). Barcelona, Spain: Gedisa.

Borrat, H. (1989). El Periódico, actor político [The Newspaper. Political Actor]. Barcelona, Spain: Gustavo Gili.

Berger, P., \& Luckmann, T. (1968). La construcción social de la Realidad [The Social Construction of Reality]. Buenos Aires, Argentina: Amorrotu.

Capdevila, A., \& Ferrán, E. (2012). El recorte de la autonomia: Posicionamiento mediático ante las declaraciones de Aznar y de Zapatero desde el análisis textual. In E. Castelló (Ed.), La mediatización del conflicto politico: Discursos y narrativas en el contextoespañol. Barcelona, Spain: Laertes.

Castelló, E. (2012). La mediatización del conflicto politico: Discursos y narrativas en el contextoespañol. Barcelona, Spain: Laertes.

Flor, V. (2011). Noves glòries a Espanya: Anticatalanisme i identitat valenciana. Barcelona, Spain: Afers.

Gomis, L. (1989). Teoria dels gèneres periodistics [Theory of journalististic genres]. Barcelona, Spain: Centre d'Investigació de la Comunicació.

Ibáñez, J. (1985). Análisis sociológico de textos o discursos. Revista Internacional de Sociología, $43,119-162$.

Jäger, S. (2001). Discurso y conocimiento. Aspectos teóricos y metodológicos de la crítica del discurso y del análisis de dispositivos. In R. Wodak \& M. Meyer (Eds.), Métodos de anàlisis crítico del discurso. Barcelona, Spain: Gedisa.

Louw, E. (2005). The media and political process. London, England: Sage.

Perales, C. (2012). Anàlisi crítica de la cobertura de l'encaix de Catalunya i Euskadi dins Espanya a través dels discursos de la premsa espanyola, catalana i basca publicats durant la Transició i fins a l'aprovació dels estatuts català i basc (1975-1979) (Doctoral thesis, Universitat Autònoma de Barcelona). Retrieved from http://www.tdx.cat/handle/10803/11 7379? show $=$ full

Perales, C., Xambó, R., \& Xicoy, E. (2012). La crisis del modelo de Estado: La sentencia del Estatut de Cataluña y el 10J. In E. Castelló (Ed.), La mediatización del conflicto politico: Discursos y narrativas en el contexto español [Critical analysis of the coverage of the lace of Catalonia and the Basque Country inside Spain through the discourses of the Spanish, Catalan and Basque press and published from the Transition to the Catalan and Basque statutes approval (1975-1979)] (pp. 61-78). Barcelona, Spain: Laertes.

Perelman, C., \& Olbrechts-Tyteca, L. (1989). Tratado de argumentación: La nueva retòrica. Madrid, Spain: Gredos.

Richardson, J. E. (2007). Analysing newspapers: An approach from critical discourse analysis. New York, NY: Palgrave Macmillan. 
Rodríguez, C. F., \& Alcaide Lara, E. R. (2007). La argumentación lingüística y sus medios de expresión. Madrid, Spain: Arco Libros.

Strömbäck, J. (2011). Mediatization and perceptions of the media's political influence. Journalism Studies, 12, 423-439.

van Dijk, T. A. (1990). La noticia como discurso: Comprensión, estructura y producción de la información. Barcelona, Spain: Paidós.

van Eemeren, F. H., \& Grootendorst, R. (2004). A systematic theory of argumentation: The pragma-dialectical approach. Cambridge, England: Cambridge University Press.

Wolsfeld, G. (2009). Political conflict. In L. L. Kaid \& C. Holtz-Bacha (Eds.), Encyclopedia of policital communication. Thousand Oaks, CA: Sage.

Xambó, R. (2012). The media in the Valencian country. Catalan Journal of Communication and Media Studies, 1, 107-122.

Xicoy, E. (2008). Interpretació periodística del conflicte basc. 'Avui', 'El Periódico' $i$ 'La Vanguardia' (setembre 1998 - abril 2000) (Doctoral thesis, Ramon Llull University). Retrieved from http://www.tdx.cat/handle/10803/9211?show=full\#

\section{Author Biographies}

Enric Xicoy is PhD in Journalism and Professor at Blanquerna School of Communication and International Relations - Ramon Llull University. He currently holds the position of Academic Secretary and has also been an Intership Coordinator. He specialized in research about how media coverage the political conflicts in Catalonia and the Basque Country.

Cristina Perales-García is $\mathrm{PhD}$ in Journalism and Communication Sciences from the Autonomous University of Barcelona (UAB) and a lecturer of Journalism at Pompeu Fabra University. Her interests include the construction of identity markers by the media acting as political agents.

Rafael Xambó is Senior Lecturer of Sociology at the Department of Sociology and Social Anthropology, University of Valencia. 